\title{
The growth and biodiversity of spruce stands in variable climate conditions - Radziejowa case study
}

\author{
Wojciech Grodzki $i^{1}$, Stawomir Ambroży ${ }^{1}$, Wojciech Gil ${ }^{2}$ \\ ${ }^{1}$ Forest Research Institute, Department of Mountain Forestry, Fredry 39, 30-605 Kraków, Poland, phone: +48 122528212, \\ fax: +48 122528202, e-mail: W.Grodzki@ibles.waw.pl \\ ${ }^{2}$ Forest Research Institute, Department of Silviculture and Genetics, Sękocin Stary, Braci Leśnej 3, 05-090 Raszyn, Poland
}

\section{Abstract}

In the experiment eight populations of Picea abies were chosen at $100 \mathrm{~m}$ intervals between $500 \mathrm{~m}$ and $1200 \mathrm{~m}$ altitude a.s.l.. In each population wood core samples were collected from 14-19 trees (126 cores total), and measured using a Corim Maxi device. At four of the eight sites (every $200 \mathrm{~m}$ in elevation between $500 \mathrm{~m}$ and $1100 \mathrm{~m}$ a.s.1.), the diversity of ground vegetation was evaluated, and temperature was recorded at every $100 \mathrm{~m}$ of altitude.

The highest average radial increment of spruce occurred between the altitudes 800-1000 $\mathrm{m}$ a.s.l., which is probably the optimum for spruce. The larger increment indices observed at higher altitudes may signify a high growth potential of spruce. It may also suggest a recent upward shift of the optimum growth zone for this tree species.

In 15 phytosociological records, the presence of 148 plant species forming plant associations: Dentario glandulosae-Fagetum typicum (sub-mountainous and mountainous form) and Abieti-Piceetum, and community Abies alba-Rubus hirtus, was documented. No relationship was found between ground vegetation species diversity (expressed by Shannon-Wiener index) and levels of stand diversity. The vegetation species diversity varied with the elevation above sea level: the highest plant diversity was found at $500 \mathrm{~m}$ a.s.l., and decreased with increasing altitude.

The potential increase in air temperatures may result in changes to the altitudinal range of many plant species including trees, and consequently in an upward shift of the boundaries of plant zones; in this case the sub-mountainous and lower mountainous forest zone. In this region, the optimal zone for Norway spruce may be restricted to the highest elevations.

\section{KEY WORDS}

climate change, forest biodiversity, spruce stands, radial increment, altitudinal variation

\section{INTRODUCTION}

The climate change forecasted could lead to a transformation of forest vegetation and related organisms, e.g. herbivorous insects and their natural enemies. Moun- tain vegetation appears to be particularly vulnerable to such changes (Hättenschwiler and Körner 1995; Peñuelas and Boada 2003). The main purpose of the BACCARA project, conducted within the European Commision 7. Framework Programme, was to develop the 
tools that will enable forest managers and policy makers to evaluate the risk of European forest biodiversity and productivity loss under climate change. One of the experiments was established in Poland (Carpathian Mountains, Radziejowa Massif), where the influence of variable climatic conditions on forest growth, stability and resistance, was assessed (Ambroży and Grodzki 2013). This paper addresses the results concerning only two aspects of the study: vegetation diversity, and the radial increment of trees.

The growth of trees is determined primarily by site conditions, but usually influenced also by their health status and vitality. A decrease in annual radial increment is one of the first symptoms of weakening in trees, before others such as crown discoloration become visible. For this reason the increment tendency (calculated as a quotient or index) can be used to assess tree vitality and/or its reaction to stressors, under the condition that data is collected from dominant trees, in order to avoid the effects of competition. Such a method has previously been used to assess the effects of air pollution (Zawada 1983), or climate variation (Zawada 1994) on trees.

Between 1979-1984 the Norway spruce stands in the upper forest zone on Radziejowa were damaged by insects of the genus Cephalcia Panzer (Hymenoptera: Pamphiliidae), mainly C. alpina Klug (Jachym 2007). In some stands that survived the outbreak with medium or light defoliation, an assessment of increment response was still possible.

In this paper the authors aim to describe the plant diversity and diameter at breast height (DBH) increment of spruce trees, in relation to changes in climatic conditions that correspond to altitude, in order to contribute to the continued evaluation of potential forest responses to predicted climate change.

\section{Material AND MEthods}

The field studies were carried out in the years 2010-2012. The study area was located in the Carpathians in the Radziejowa Massif (Beskid Sądecki, Poland).

The Radziejowa Massif was formed from the rocks of the Carpathian flysch. It is a sequence of shales regularly interbedded with sandstones (Margielewski 2000). Rocks of the Carpathian flysch make up the bedrocks of clay soils. According to the climatic conditions, brown soils develop at low and medium elevations, and podzolic soils at the highest elevations (Maciaszek 2000). The annual precipitation in the Beskid Sacecki region is approximately $800-1100 \mathrm{~mm}$, and is a function of elevation (being lowest at $500 \mathrm{~m}$ a.s.l., and highest at $1200 \mathrm{~m}$ a.s.1.). Mean annual temperature is approximately $4-7^{\circ} \mathrm{C}$, and is negatively correlated with elevation (Brzeźniak and Czemerda 2000).

The study area was located in two vegetation stages in different altitudinal zones. The lower forest stage (dominated by beech) extends up to an altitude of $1100 \mathrm{~m}$ a.s.1., while the upper forest stage (dominated by Norway spruce) on the southern slopes of Radziejowa Massif, is well developed above $1100 \mathrm{~m}$ a.s.l. (Staszkiewicz 2000).

The study area is covered by mixed Norway spruce Picea abies (L.) H. Karst., European beech Fagus sylvatica L., and silver fir Abies alba Mill. stands, but Norway spruce is the dominant species. The main forest management strategy has combined objectives: predominantly to protect soil and water quality, and to promote 'close-to-nature forestry' (Duncker et al. 2012). These strategies require maintenance of the forest cover (i.e. 'continuous cover forestry'). This means that in most cases stands are naturally regenerated under a canopy of older trees (Szewczyk 2000).

Eight populations of Picea abies growing on elevations from $500 \mathrm{~m}$ to $1200 \mathrm{~m}$ a.s.l. (at every $100 \mathrm{~m}$ of elevation) were sampled and measured (fig. 1, tab. 1). In order to obtain the largest time-series possible, the oldest spruce stands were chosen from the limited number available at each elevation. In each population a single wood core was collected from each tree using a Pressler borer at $1.3 \mathrm{~m}$ above ground level, from 14-19 trees with an above-average DBH, in order to determine the response of spruce growth to various climate conditions. The cores were measured using a Corim Maxi device. At each altitude the average 30-year increment of Norway spruce was calculated along with increment indices, based on the comparison of mean yearly increment within selected decades (Zawada 1983, modified). Two indices were calculated at all altitudes: WP00 (a ratio between 1991-2000 and 1981-1990), and WP10 (a ratio between 2001-2010 and 1991-2000), in order to determine the increment tendency over last two decades. The indices were calculated as follows: 


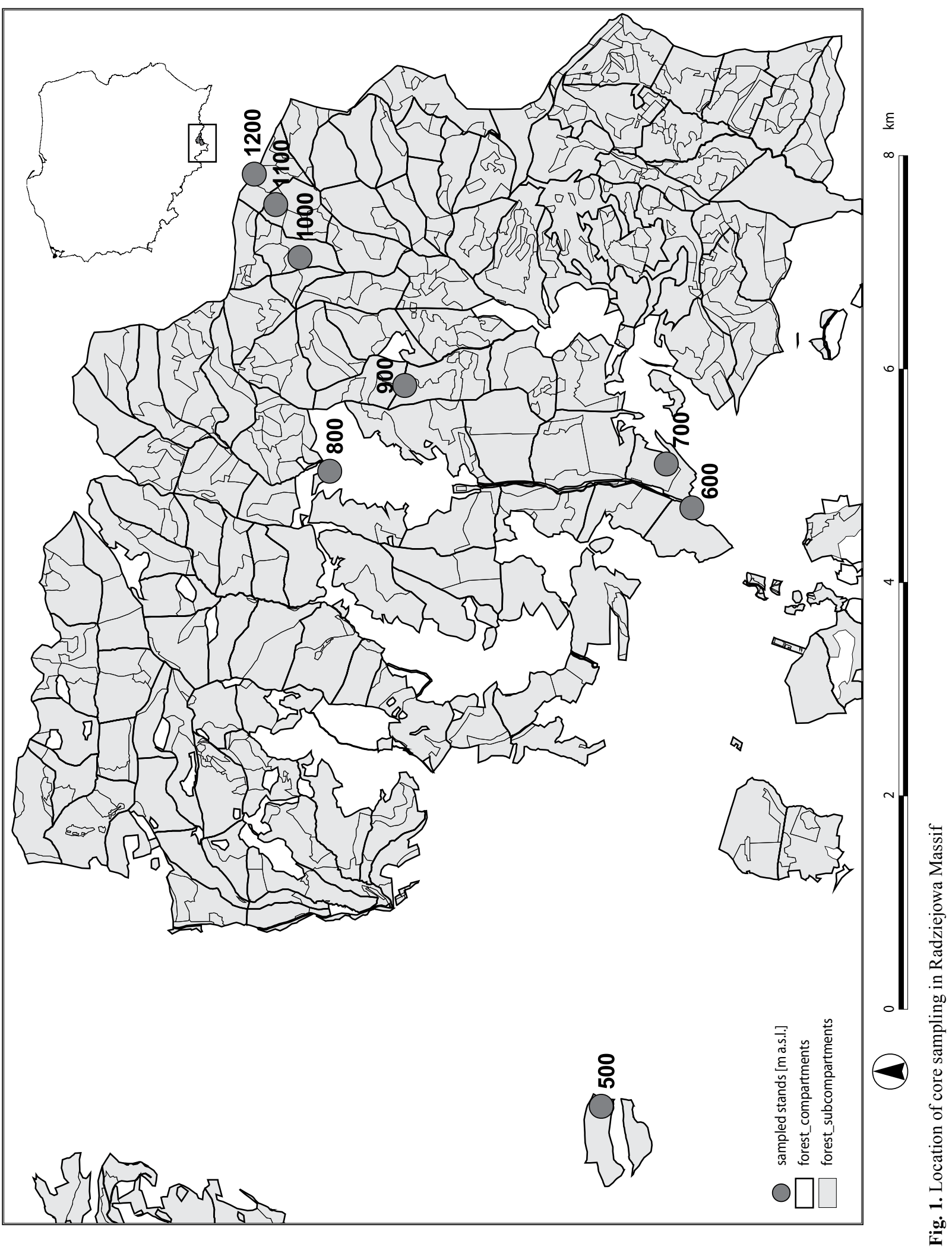




$$
W P 00=\frac{I_{1991-2000}}{I_{1981-1990}}
$$

where:

$I_{1991-2000}$ - diameter increment in the decade 1991-2000 [mm],

$I_{1981-1990}$ - diameter increment in the decade 1981-1990 [mm].

$$
W P 10=\frac{I_{2001-2010}}{I_{1991-2000}}
$$

where:

$I_{2001-2010}$ - diameter increment in the decade 2001-2010 [mm],

$I_{1991-2000}$ - diameter increment in the decade 1991-2000 [mm].

Additionally, for the samples taken in the upper forest stage (1100 and $1200 \mathrm{~m}$ a.s.1.), indices were calculated to correspond with the timing of Cephalcia sp.: "damage" - $W P_{d}(1976-1985$ vs. 1966-1975), and "recovery" - $W P_{r}$ (1986-1995 vs. 1976-1985), in order to assess the reduction in increment due to defoliation, and the recovery process over the following years. These indices were calculated as follows:

$$
W P_{d}=\frac{I_{1976-1985}}{I_{1966-1975}}
$$

where:

$I_{1976-1985}$ - diameter increment in the decade 1976-1985 [mm],

$I_{1966-1975}$ - diameter increment in the decade 1966-1975 [mm].

$$
W P_{r}=\frac{I_{1986-1995}}{I_{1976-1985}}
$$

where:

$I_{1986-1995}$ - diameter increment in the decade 1986-1995 [mm],

$I_{1976-1985}$ - diameter increment in the decade 1976-1985 [mm].

Level of defoliation was determined using archive data (Jachym 2008).

Temperature loggers were installed at each elevation, in order to determine the annual average temperature variation as it relates to the altitude a.s.l. (Urban 2010).

\begin{tabular}{|c|c|c|c|c|c|c|c|c|}
\hline $\begin{array}{c}\text { Com- } \\
\text { partment }\end{array}$ & Coordinates & $\begin{array}{l}\text { Altitude } \\
\text { a.s.1. } \\
{[\mathrm{m}]}\end{array}$ & \begin{tabular}{|c|} 
Prop. \\
of spruce \\
{$[\%]$}
\end{tabular} & $\begin{array}{c}\text { Mean age } \\
\text { of stand from FMP* } \\
{[\text { years }]}\end{array}$ & $\begin{array}{c}\text { Stand } \\
\text { density }\end{array}$ & $\begin{array}{c}\text { Number of } \\
\text { sampled trees }\end{array}$ & $\begin{array}{c}\text { Mean DBH } \\
\text { of sampled } \\
\text { trees }[\mathrm{cm}]\end{array}$ & $\begin{array}{c}\text { Mean age } \\
\text { of sampled trees } \\
\text { [years] }\end{array}$ \\
\hline $97 \mathrm{a}$ & $\begin{array}{l}49^{\circ} 25^{\prime} 27^{\prime \prime} \mathrm{N} \\
20^{\circ} 28^{\prime} 37^{\prime \prime} \mathrm{E}\end{array}$ & 500 & 40 & 60 & 0.6 & 15 & 46.8 & 98 \\
\hline $36 \mathrm{f}$ & $\begin{array}{l}49^{\circ} 24^{\prime} 54^{\prime \prime} \mathrm{N} \\
20^{\circ} 33^{\prime} 08^{\prime \prime} \mathrm{E}\end{array}$ & 600 & 30 & 45 & 0.7 & 14 & 46.0 & 61 \\
\hline $36 \mathrm{a}$ & $\begin{array}{l}49^{\circ} 25^{\prime} 25^{\prime \prime} \mathrm{N} \\
20^{\circ} 33^{\prime} 32^{\prime \prime} \mathrm{E}\end{array}$ & 700 & 40 & regeneration phase & 0.4 & 15 & 41.6 & 83 \\
\hline $44 \mathrm{a}$ & $\begin{array}{l}49^{\circ} 26^{\prime} 45^{\prime \prime} \mathrm{N} \\
20^{\circ} 33^{\prime} 32^{\prime \prime} \mathrm{E}\end{array}$ & 800 & 30 & 50 & 0.7 & 15 & 41.8 & 69 \\
\hline $28 \mathrm{~b}$ & $\begin{array}{l}49^{\circ} 26^{\prime} 22^{\prime \prime} \mathrm{N} \\
20^{\circ} 34^{\prime} 10^{\prime \prime} \mathrm{E}\end{array}$ & 900 & 60 & 65 & 0.7 & 19 & 41.9 & 62 \\
\hline $19 \mathrm{~d}$ & $\begin{array}{l}49^{\circ} 26^{\prime} 53^{\prime \prime} \mathrm{N} \\
20^{\circ} 35^{\prime} 11^{\prime \prime} \mathrm{E}\end{array}$ & 1000 & 20 & 45 & 0.7 & 14 & 39.9 & 81 \\
\hline $17 \mathrm{a}$ & $\begin{array}{l}49^{\circ} 27^{\prime} 05^{\prime \prime} \mathrm{N} \\
20^{\circ} 35^{\prime} 29^{\prime \prime} \mathrm{E}\end{array}$ & 1100 & 60 & regeneration phase & 0.2 & 17 & 45.7 & 108 \\
\hline $14 \mathrm{~d}$ & $\begin{array}{l}49^{\circ} 27^{\prime} 033^{\prime \prime} \mathrm{N} \\
20^{\circ} 35^{\prime} 56^{\prime \prime} \mathrm{E}\end{array}$ & 1200 & 80 & 60 & 0.9 & 17 & 32.6 & 65 \\
\hline
\end{tabular}

At four altitudes between $500 \mathrm{~m}$ to $1100 \mathrm{~m}$ a.s.l. (every $200 \mathrm{~m}$ ), the diversity of ground vegetation

Tab. 1. Characteristics of sampled spruce stands

\footnotetext{
${ }^{*}$ FMP - Forest Management Plan.
} 
was evaluated using a set of 15 experimental plots $(20 \times 20 \mathrm{~m}$ squares, $0.04 \mathrm{ha})$. At each elevation four plots were selected according to a tree species composition gradient: from pure/nearly pure Norway spruce to mixed (four diversity levels per altitude, with the exception of $1100 \mathrm{~m}$ a.s.1., which had three due to limited tree species diversity). This means, that at each elevation the first plot represented pure (or nearly pure) spruce stand and the last plot - stands with the richest composition (up to seven species).

On each plot the vegetation was described via phytosociological record, using the Braun-Blanquet method, in order to determine plant associations and communities. For each phytosociological record, the Shannon-Wiener $\left(H^{\prime}\right)$ species diversity index was calculated using the formula as follows:

$$
H^{\prime}=-\sum p_{i} \ln p_{i}
$$

where:

$p_{i}$ is the proportion of individuals of species $i$.

The species coverage values in the five degree Braun-Blanquet scale were converted into the van der Maarel (1979) scale.

Data was analyzed via correlations, one-way ANOVA and post-hoc tests (Tukey RIR) using STATISTICA 5 software (StatSoft 1997).

\section{Results}

Mean annual temperature, estimated from the data collected in the period 15.05.2010 to 14.05.2011 for the Radziejowa Massif, is negatively correlated with altitude $\left(\mathrm{r}^{2}=0.94, \mathrm{p}<0.001\right)$ (fig. 2). The highest mean value $\left(6.92^{\circ} \mathrm{C}\right)$ was found at $500 \mathrm{~m}$ a.s.l., decreasing constantly with increasing altitude to the lowest mean value $\left(3.71^{\circ} \mathrm{C}\right)$ at $1200 \mathrm{~m}$ a.s.l. On the points located in the upper forest stage (1100-1200 m a.s.1.), the mean temperature $\left(4.04^{\circ} \mathrm{C}\right)$ was much lower than in the zones $500-700 \mathrm{~m}\left(6.52^{\circ} \mathrm{C}\right)$, and $800-1000 \mathrm{~m}\left(5.37^{\circ} \mathrm{C}\right) \mathrm{m}$ a.s.l., and the differences between zones were statistically significant (ANOVA F $=34650.83 ; \mathrm{p}<0.001$ ).

In total 126 spruce trees were sampled. The DBH of sampled trees was $41.9 \mathrm{~cm}$ on average, varying between individual locations within a range $32.6-46.8 \mathrm{~cm}$. The mean age of these trees varied from 61 to 108 years old, and according to the Forest Management Plan (tab. 1), was generally higher than the stand age.

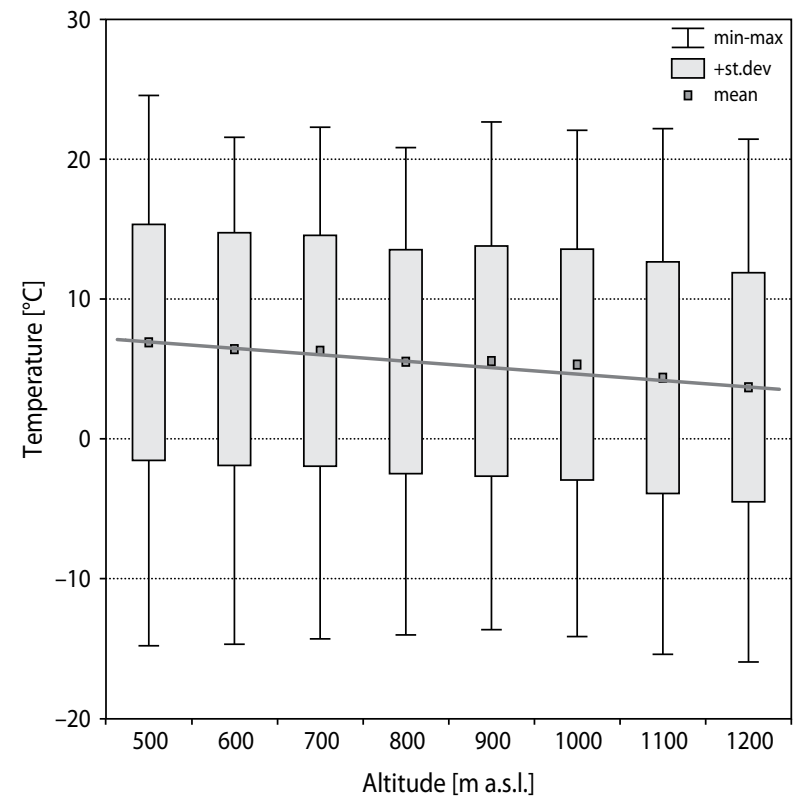

Fig. 2. Thermal patterns - mean annual temperature at the elevations 500-1200 m a.s.1.

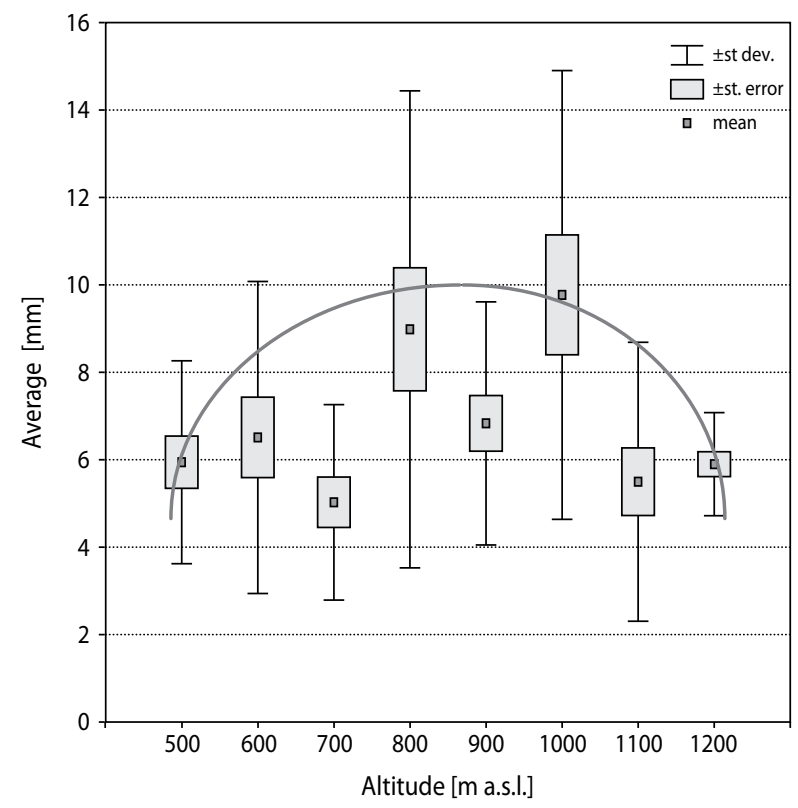

Fig. 3. Average 30-year radial increment of Norway spruce at individual altitudes

The 30-year average DBH increment of eight spruce populations studied significantly differed between indi- 
vidual altitudes (ANOVA $\mathrm{F}=3.586 ; \mathrm{p}<0.01$ ), being highest at the altitudes 800 and $1000 \mathrm{~m}$ above sea level (only these two altitudes were statistically different), while the stands at other elevations had a much lower average increment. The trend line of the radial increment is at its maximum between the elevations where stands were characterized by highest growth (fig. 3).

The increment index calculated using the data from last three decades (WP00 and WP10) has the highest value in the stands growing at the highest locations, at more than 900 meters above sea level (tab. 2). These stands are characterized by increasing growth in recent decades, while the others have decreased in growth or displayed significant variation in the subsequent decades. Generally, the yearly increment did not differ significantly between decades at the locality level, regardless of the value of calculated indices, except in two cases where differences at $\mathrm{p}<0.05$ were found (tab. 2).

Damage caused by Cephalcia during the outbreak from 1979-1984 affected only the stands in the higher forest zone. Among those sampled, only the stand growing at $1200 \mathrm{~m}$ a.s.l. was affected by moderate (31-60\%) defoliation, resulting in a reduced radial increment between 1979-1981, which was especially visible when compared with an undamaged stand (fig. 4). The differ- ences between the decades analyzed were statistically significant only in the damaged stand, which demonstrated rapid recovery in increment during the decade following defoliation (tab. 3).

Tab. 2. Values of radial increment indices for the stands on the observation plots in the Radziejowa, and the significance of differences in the mean increment in the periods used for the increment index calculation (One-way ANOVA)

\begin{tabular}{|c|c|c|c|c|c|c|}
\hline \multirow[b]{2}{*}{$\stackrel{\frac{D}{D}}{\stackrel{D}{E}}$} & \multirow[b]{2}{*}{$\begin{array}{l}\S \\
\vdots \\
\vdots\end{array}$} & \multicolumn{2}{|c|}{ ANOVA } & \multirow[b]{2}{*}{$\stackrel{0}{\varrho}$} & \multicolumn{2}{|c|}{ ANOVA } \\
\hline & & 工 & 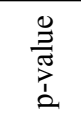 & & L & 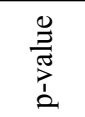 \\
\hline 500 & 1.01 & 0.0253 & n.s. & 0.96 & 0.4595 & n.s. \\
\hline 600 & 0.59 & 4.9510 & $<0.05$ & 1.10 & 1.0891 & n.s. \\
\hline 700 & 0.96 & 1.5399 & n.s. & 0.89 & 0.2762 & n.s. \\
\hline 800 & 0.82 & 1.4585 & n.s. & 0.80 & 2.9881 & n.s. \\
\hline 900 & 0.81 & 3.6668 & n.s. & 0.81 & 5.1882 & $<0.05$ \\
\hline 1000 & 1.17 & 0.1744 & n.s. & 1.07 & 0.5253 & n.s. \\
\hline 1100 & 1.14 & 0.3734 & n.s. & 1.12 & 0.0258 & n.s. \\
\hline 1200 & 1.15 & 1.6167 & n.s. & 1.11 & 1.1047 & n.s. \\
\hline
\end{tabular}

In the phytosociological records described on the plots, 148 plant species were recorded: 128 species

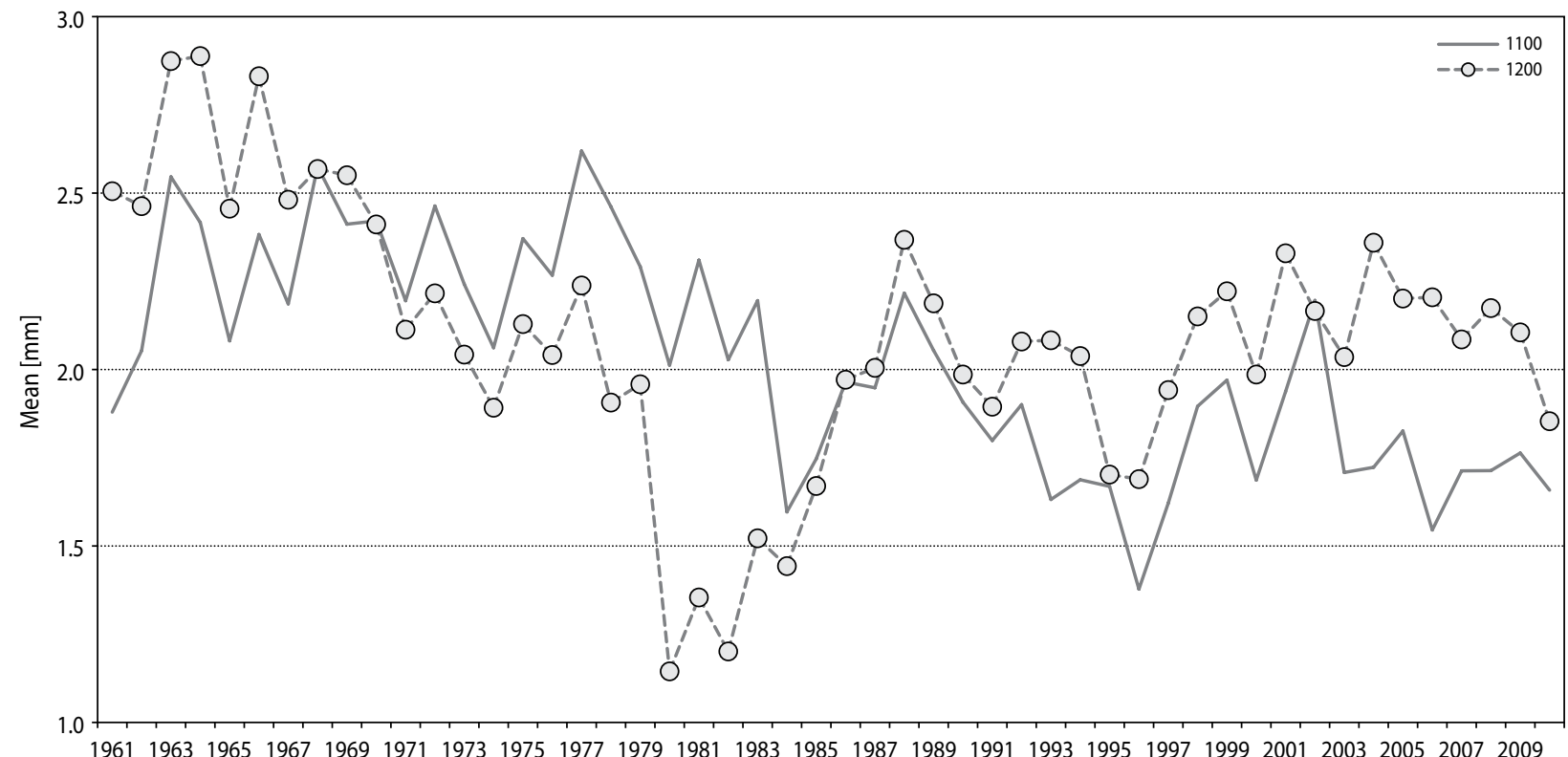

Fig. 4. Mean yearly increment of trees in upper forest stage at 1100 (undamaged) and 1200 (damaged by Cephalcia in 1979-1984) $\mathrm{m}$ a.s.1. in the period 1961-2010 
of vascular plants (including 26 species of trees and shrubs), and 20 species of mosses. Two associations and one community were identified (tab. 4):

- Dentario glandulosae-Fagetum typicum Klika 1927 em. W. Mat. 1964, represented by the typical sub-association in two altitudinal forms: sub-mountainous form and mountainous form;

- Abieti-Piceetum Pawł. et Kulcz. 1923 em. J. Mat. 1978;

- Abies alba-Rubus hirtus.

Tab. 3. Increment indices of stands in the upper forest zone (from $1100 \mathrm{~m}$ a.s.l.), corresponding to the period of defoliation caused by Cephalcia spp.

\begin{tabular}{|c|c|c|c|c|c|c|}
\hline \multirow[b]{2}{*}{ Period } & \multicolumn{3}{|c|}{$1100 \mathrm{~m}$ a.s.l. } & \multicolumn{3}{|c|}{$1200 \mathrm{~m}$ a.s.l. } \\
\hline & $\sum^{0}$ & 工 & 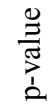 & $\sum^{n}$ & L & $\begin{array}{l}\stackrel{0}{J} \\
\frac{\pi}{7} \\
1 \\
0\end{array}$ \\
\hline $\begin{array}{l}\text { decline: } \\
\text { 1976-85/1966-75 }\end{array}$ & 0.83 & 0.5105 & n.s. & 0.71 & 5.2341 & $<0.05$ \\
\hline $\begin{array}{l}\text { recovery: } \\
\text { 1986-95/1976-85 }\end{array}$ & 0.83 & 0.6868 & n.s. & 1.23 & 3.9617 & n.s. \\
\hline
\end{tabular}

No relationship was found between the species diversity of ground vegetation, expressed by the ShannonWiener index, and level of stand diversity at individual altitudes (fig. 5).

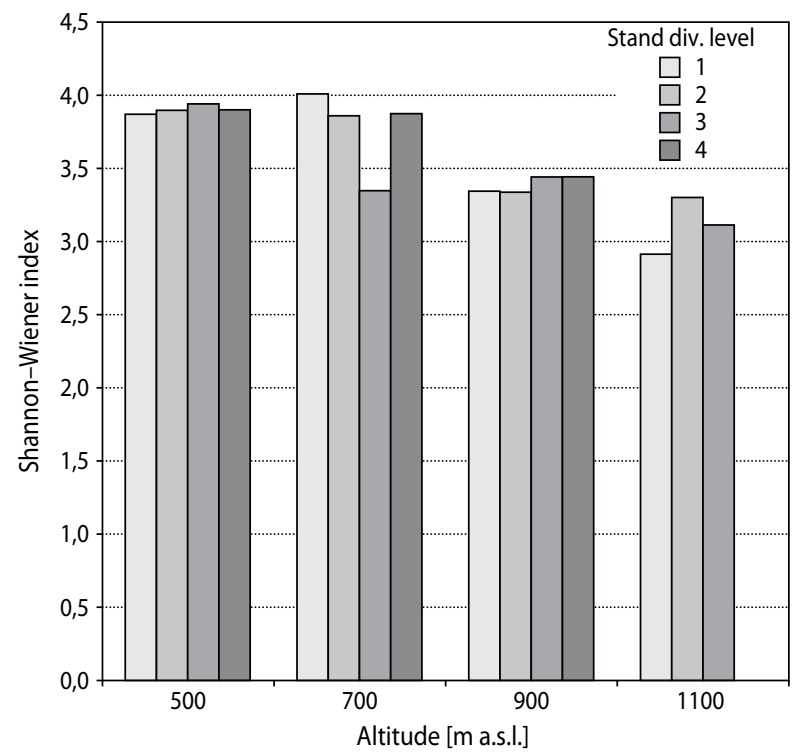

Fig. 5. The Shannon-Wiener index calculated for ground vegetation in stands representing different tree diversity levels, at the various elevations

The average Shannon-Wiener $\left(H^{\prime}\right)$ index calculated for pooled data concerning vegetation at four elevations demonstrates a clear trend of plant species diversity, decreasing with altitude $\left(\mathrm{r}^{2}=0.77, \mathrm{p}<0.001\right)$ : the highest $\left(H^{\prime}=3.90\right)$ at $500 \mathrm{~m}$ a.s.l., the lowest $\left(H^{\prime}=3.11\right)$ at $1100 \mathrm{~m}$ a.s.l. (fig. 6).

Tab. 4. Forest vegetation on 15 plots located at four altitudinal levels on Radziejowa

\begin{tabular}{|c|c|l|l|}
\hline $\begin{array}{c}\text { Elevation } \\
{[\mathrm{m} \text { a.s.1.] }}\end{array}$ & $\begin{array}{c}\text { Stand } \\
\text { diversity } \\
\text { level }\end{array}$ & \multicolumn{1}{|c|}{ Phytosociological plant association or community } & European forest types* \\
\hline 500 & $1-4$ & $\begin{array}{l}\text { Dentario glandulosae-Fagetum typicum sub-mountainous } \\
\text { form }\end{array}$ & 7.5 Carpathian mountainous beech forest \\
\hline 700 & $1,2,4$ & Dentario glandulosae-Fagetum typicum mountainous form & 7.5 Carpathian mountainous beech forest \\
\cline { 2 - 5 } & 3 & Abies alba-Rubus hirtus community & $\begin{array}{l}3.2 \text { Subalpine and mountainous spruce and } \\
\text { mountainous mixed spruce-silver fir -forest }\end{array}$ \\
\hline \multirow{2}{*}{900} & $1-4$ & Abies alba-Rubus hirtus community & $\begin{array}{l}3.2 \text { Subalpine and mountainous spruce and } \\
\text { mountainous mixed spruce-silver fir -forest }\end{array}$ \\
\hline \multirow{2}{*}{1100} & 1,2 & Abieti-Piceetum & $\begin{array}{l}3.2 \text { Subalpine and mountainous spruce and } \\
\text { mountainous mixed spruce-silver fir -forest }\end{array}$ \\
\cline { 2 - 5 } & 3 & Dentario glandulosae-Fagetum typicum mountainous form & 7.5 Carpathian mountainous beech forest \\
\hline
\end{tabular}

* www.eea.europa.eu. 2007. European forest types. Categories and types for sustainable forest management reporting and policy. EEA Technical report No 9/2006: 5-111. 


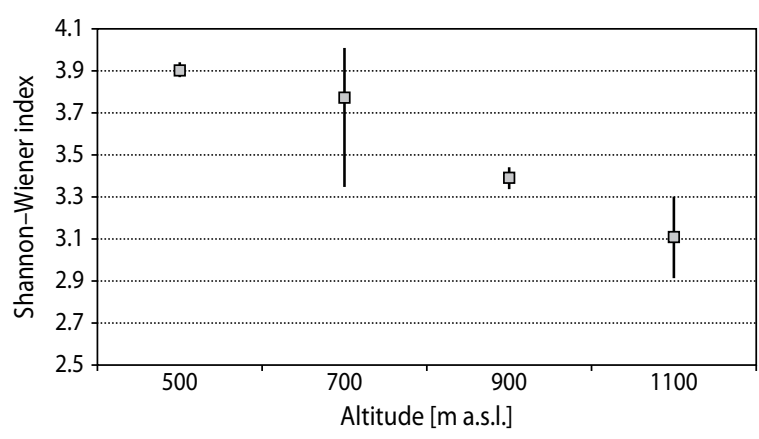

Fig. 6. Ground vegetation diversity at individual altitudes (level of experimental plots)

\section{Discussion}

The significant differences found in the value of 30 year radial increment of spruce populations at different elevations may indicate the influence of several factors on tree growth, other than climatic conditions. A decrease in the increment of spruce stands growing in the highest parts of the Radziejowa Massif has already been recorded by Zawada (1994). The author pointed out that the defoliation caused by folivorous insects was the main stressor for the spruce trees that were weakened and then attacked by bark beetles. One of the measurable effects of this damage is the reduction of radial tree growth (Čapek 1962), which usually is temporary and - in cases where damage is moderate - is proceeded by rapid recovery over the following years. This kind of reaction, which was recorded in our case study but also previously shown by Jachym (2011) in relation to the degree of damage, suggests that stands on the highest parts of Radziejowa are of relatively high vitality and growth potential, especially in the upper forest zone. In the Norway spruce stands in Western Sudetes the radial increment decreased with altitude, but after an extended outbreak of Zeiraphera griseana (Hb.) in 1977-1983 a similar recovery was not recorded - probably due to a longlasting water deficiency (Grodzki 1998).

Based on the increment data, it seems that in the case of Radziejowa one should distinguish two main features of Norway spruce: productivity (expressed by the radial increment value), and vitality (expressed by the increment indices describing its dynamics). The variation in mean growth increment in over a 30 -year period suggests that the optimum zone for Norway spruce productivity lies between 800 and $1000 \mathrm{~m}$ a.s.l. On the other hand the highest increment indices were found in the trees growing on higher altitudes, that indicate greater growth potential of stands in the upper forest stage (naturally dominated by Norway spruce), where the productivity of trees (with respect to increment size) is more limited by both climatic and biotic factors. This was clearly demonstrated based on the data acquired from a relatively limited samples of trees, though may not be true in relation to the increment of stands. This result, however, concerns the growth of mature trees and does not apply to regeneration, as the optimum altitude for $P$. abies juveniles is lower than that for adults, probably because of limitations on reproduction or establishment of seedlings at higher altitudes (Rabasa et al. 2013).

There are many environmental factors influencing Norway spruce growth that differ between geographical regions and altitudinal zones (Mäkinen et al. 2002). The lower radial increment of spruce stands growing on low altitude locations of the Radziejowa Massif may be also caused by other factors. Precipitation in the lower elevations is not as high as in the crest positions of Radziejowa (Brzeźniak and Czemerda 2000), and fluctuating rainfall in the growing season may negatively influence the growth of Norway spruce, which is a species extremely susceptible to changes in water regime (Kurjak et al. 2010). The lack of water is the main growth limiting factor at low altitudes, while at intermediate altitudes this effect is not so strong (Mäkinen et al. 2002). In addition, the stands occupying lower elevations of the massif are characterized by a higher frequency of pathogenic fungi, such as white-rot fungus Heterobasidion parviporum ( $\mathrm{Fr}$.) Niemelä \& Korhonen, bulbous honey fungus Armillaria cepistipes Velen, and dark honey fungus Armillaria ostoyae (Romagn.) Herink, than those at higher altitudes of Radziejowa (Grodzki et al. 2012). The occurrence of these pathogens is also driven by hydrothermic conditions - water deficiency in particular is known as a stimulating factor for Armillaria spp. (Desprez-Lousteau et al. 2006). Thus, it can also be considered as one reason for lower growth of some of spruce stands investigated.

The forest plant associations and communities found on research plots located in the Radziejowa Massif do not represent all the variability of forest vegeta- 
tion present. Above the range of elevations examined, the association Plagiothecio-Piceetum (Schaf., Pawł. et Kulcz. 1923) J. Mat. 1977 can be found, and below, the association Tilio-Carpinetum Tracz. 1962 (Myczkowski and Grabski 1962; Staszkiewicz 1995, 2000). Within the range of elevations studied, the association Luzulo luzuloidis-Fagetum Markgr. 1932. em. Meusel 1937 also occurs, as well as communities of artificial origin in spruce-dominated stands, which have undetermined phytosociological status (Fabijanowski 1962; Myczkowski and Grabski 1962; Staszkiewicz 1995, 2000) and were widespread in the past. As studies have shown, despite the dominance of spruce in the stand, such plant communities can now be readily recognized. This demonstrates the significant progress of vegetation change processes towards sustainable forests, taking place in communities of planted stands where Norway spruce is dominant.

The relationship between plant biodiversity and elevation can be described by models (Nogués-Bravo et al. 2008). The main ones being:

- a monotonic species richness model, in which species richness are assumed to decrease with altitude,

- a hump-shaped species richness model, in which species richness is assumed to peak within the lower half of the gradient,

- a mid-domain-effect model with a peak in richness in the middle of the gradient as a consequence of geometric constraints and two hard boundaries.

The dependency of biodiversity on altitude, observed in the Radziejowa Massif, is best described by the first of these models.

\section{Conclusions}

- At the altitudes 800-1000 $\mathrm{m}$ a.s.l. the average radial increment of spruce was at its highest. It is probably the optimum for spruce, with favourable climatic conditions and low competition. The reduction in average increment at $900 \mathrm{~m}$ a.s.l. may be due to the occurrence of limiting factors (e.g. reduced water, prevalence of fungi).

- The increase of radial increment indices with altitude and rapid recovery following insect defoliation can be considered as an indication of the high growth potential of spruce, which may suggest an altitudinal shift of the optimum growth zone for spruce in recent years.

- The vegetation of Radziejowa Massif is characterised by a large (148) number of species. The highest plant diversity, found at $500 \mathrm{~m}$ a.s.l., decreased with increasing altitude.

- The possible increase in air temperatures may result in changes in the vertical range of many plant species including trees, and as a consequence, in an upward shift of the boundaries of plant zones, in this case the sub-mountainous and lower mountainous forest zones. In this scenario, the optimal performance of Norway spruce could be limited to the highest altitudes.

\section{Acknowledgements}

The presented research was conducted within the project "Biodiversity And Climate Change - A Risk Analysis (BACCARA)" financed by European Commission 7. Framework Programme (contract no 226299) in 2009-2012.

The paper is dedicated to the memory of Dr. Jerzy Zawada deceased in 2009.

\section{References}

Ambroży S., Grodzki W. 2013. Biodiversity And Climate Change, A Risk Analysis (BACCARA): Carpathian case - goals and assumptions. In: The Carpathians: Integrating Nature and Society Towards Sustainability (eds.: J. Kozak et al.). Environmental Science and Engineering, , Springer-Verlag Berlin Heidelberg, 425-428, DOI: 10.1007/978-3642-12725-0 29.

Brzeźniak E., Czemerda A. 2000. Klimat. In: Przyroda Popradzkiego Parku Krajobrazowego (ed.: J. Staszkiewicz). Popradzki Park Krajobrazowy, Stary Sącz, 37-46 (in Polish).

Čapek M. 1962. Über den Einfluß des Kahlfraßes von Zeiraphera diniana Guen. auf den Jährlichen $\mathrm{Zu}$ wachs der Fichte. Schweizerische Zeitschrift für Forstwesen, 11, 635-642.

Desprez-Lousteau M.-L., Marçais B., Nageleisen L.-M., Piou D., Vannini A. 2006. Interactive effects of 
drought and pathogens in forest trees. Annals of Forest Science, 63, 597-612.

Duncker P.S., Barreiro S.M., Hengeveld G.M., Lind T., Mason W.L., Ambroży S., Spiecker H. 2012. Classification of Forest Management Approaches: A New Conceptual Framework and Its Applicability to European Forestry. Ecology and Society, 17 (4), 51, DOI: 10.5751/ES-05262-170451.

Fabijanowski J. 1962. Lasy zlewni Białej Wody i ogólne wytyczne ich zagospodarowania. Roczniki Nauk Rolniczych, 96 (D), 113-148 (in Polish).

Grodzki W. 1998. Wybrane objawy stresu w świerczynach Sudetów Zachodnich w aspekcie oddziaływania czynników abiotycznych i skutków masowego pojawu wskaźnicy modrzewianeczki Zeiraphera griseana $\mathrm{Hb}$. (Lepidoptera: Tortricidae). Prace Instytutu Badawczego Leśnictwa Seria A, 848, 127-155 (in Polish).

Grodzki W., Ambroży S., Hilszczańska D., Hilszczański J., Żółciak A. 2012. Radziejowa in the Carpathians - an example of forest biodiversity in altitudinally diversified landscape. In: Tackling climate change: the contribution of forest scientific knowledge. International Conference, Tours 2012, Book of abstracts, 268.

Hättenschwiler S., Körner C. 1995. Responses to recent climate warming of Pinus sylvestris and Pinus cembra within their montane transition zone in the Swiss Alps. Journal of Vegetation Science, 6, 357-368.

Jachym M. 2007. Web-spinning sawflies of the genus Cephalcia Panzer (Hymenoptera, Pamphiliidae) in the Picea abies forests of the Beskidy Mountains (Poland). Journal of Forest Science, 53, (Special Issue), 63-68.

Jachym M. 2008. Stan i kierunki rozwoju drzewostanów na obszarach pogradacyjnych w Karpatach. Sprawozdanie naukowe, Instytut Badawczy Leśnictwa, Poland (in Polish).

Jachym M. 2011. Dynamics of spruce stands increment in Beskidy mountains (Poland) in the mass outbreak of Cephalcia Panzer (Hymenoptera, Pamphiliidae). Berichte Freiburger Forstliche Forschung, 89, 186-188.

Kurjak D., Konôpka B., Priwitzer T., Kmet' J., Ditmarová L. 2010. Physiological aspects of spruce decline in the Beskids. In: Spruce forests decline in the Beskids (eds.: Z. Sitková, T. Hlásny). National Forest Centre - Forest Research Institute Zvolen, Czech University of Life Sciences Prague, Forestry and Game Management Research Institute Jíloviště-Strnady, 107-129.

Maarel van der E. 1979. Transformation of coverabundance values in phytosociology and its effect on community similarity. Vegetatio, 39, 97-114.

Maciaszek W. 2000. Gleby. In: Przyroda Popradzkiego Parku Krajobrazowego (ed.: J. Staszkiewicz). Popradzki Park Krajobrazowy, Stary Sącz, 47-56 (in Polish).

Mäkinen H., Nöjd P., Kahle H-P., Neumann U., Tveite B., Mielikäinen K., Röhle H., Spiecker H. 2002. Radial growth variation of Norway spruce ( $P i$ cea abies (L.) Karst.) across latitudinal and altitudinal gradients in central and northern Europe. Forest Ecology and Management, 171 (3), 243-259.

Margielewski W. 2000. Budowa geologiczna. In: Przyroda Popradzkiego Parku Krajobrazowego (ed.: J. Staszkiewicz). Popradzki Park Krajobrazowy, Stary Sącz, 27-35 (in Polish).

Myczkowski S., Grabski S. 1962. Zbiorowiska leśne doliny Czarnej Wody w Beskidzie Sądeckim. Roczniki Nauk Rolniczych, 96 (D), 149-191 (in Polish).

Nogues-Bravo D., Araujo M.B., Romdal T. Rahbek C. 2008. Scale effects and human impact on the elevational species richness gradients. Nature, 453, 216-219.

Peñuelas J., Boada M. 2003. A global change-induced biome shift in the Montseny mountains (NE Spain). Global Change Biology, 9, 131-140.

Rabasa S.G., Granda E., Benavides R., Kunstler G., Espelta J.M., Ogaya R., Scherer-Lorenzen M., Gil W., Grodzki W., Ambrozy S., Bergh J., Hódar J.A., Zamora R., Valladares F. 2013. Disparity in elevational shifts of European trees in response to recent climate warming. Global Change Biology, DOI: $10.1111 /$ gcb.12220.

Staszkiewicz J. 1995. Sądecczyzna. In: Szata roślinna Parków Narodowych i Rezerwatów Polski Południowej (eds.: Z. Mirek, J.J. Wójcik). Polish Botanical Studies Guidebook, Ser. 12, 187-210.

Staszkiewicz J. 2000. Historia oraz pionowe i poziome zróżnicowanie roślinności. In: Przyroda Popradz- 
kiego Parku Krajobrazowego (ed.: J. Staszkiewicz). Popradzki Park Krajobrazowy, Stary Sącz, 129-135 (in Polish).

StatSoft, Inc. 1997. STATISTICA for Windows [Computer program manual]. Tulsa, OK: StatSoft, Inc., http://www.statsoft.com.

Szewczyk A. 2000. Lasy i gospodarka leśna. In: Przyroda Popradzkiego Parku Krajobrazowego (ed.: J. Staszkiewicz). Popradzki Park Krajobrazowy, Stary Sącz, 109-118 (in Polish).

Urban G. 2010: Ocena wybranych metod obliczania średniej dobowej, miesięcznej i rocznej wartości temperatury powietrza (na przykładzie Sudetów Zachodnich i ich przedpola). Opera Corcontica, 47 (1), 23-34 (in Polish).

www.eea.europa.eu. 2007. European forest types. Categories and types for sustainable forest management reporting and policy. EEA Technical Report 9/2006, 5-111.

Zawada J. 1983. Metoda oceny stanu zdrowotnego drzewostanów znajdujących się pod wpływem emisji przemysłowych. Las Polski, 10, 19-20.

Zawada J. 1994. „Małe Sudety” na Radziejowej. Las Polski, 8, 10-11. 